\title{
Analysis of Body Composition and Pain Intensity in Women with Chronic Pelvic Pain Secondary to Endometriosis
}

\section{Análise da composição corporal e intensidade de dor em mulheres com dor pélvica crônica secundária a endometriose}

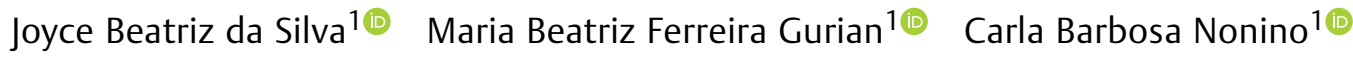 \\ Omero Benedito Poli-Neto ${ }^{10}$ Antonio Alberto Nogueira ${ }^{1(0)}$ Francisco José Candido dos Reis ${ }^{10}$ \\ Júlio Cesar Rosa-e-Silva1뭉
}

${ }^{1}$ Department of Gynecology and Obstetrics, Faculdade de Medicina de Ribeirão Preto, Universidade de São Paulo, Ribeirão Preto, Brazil

Address for correspondence Júlio Cesar Rosa-e-Silva, PhD, Avenida Bandeirantes 3.900, Ribeirão Preto, SP, 14049-900, Brazil Rev Bras Ginecol Obstet 2020;42(8):486-492. (e-mail: juliocrs@usp.br).

\section{Abstract \\ Keywords \\ - chronic pelvic pain \\ - fat percentage \\ - pain intensity \\ - anxiety \\ - depression}

\section{Resumo}

Objective To determine the average body composition (percentage of body fat), the anthropometric markers, and the intensity of clinical pain in women with a clinical diagnosis of chronic pelvic pain (CPP) secondary to endometriosis.

Methods A case-control study performed with 91 women, 46 of whom with CPP secondary to endometriosis and 45 of whom with CPP secondary to other causes. They underwent an evaluation of the anthropometric parameters by means of the body mass index (BMI), the perimeters (waist, abdomen, hip), and the percentage of body fat (\%BF), which were assessed on a body composition monitor by bioimpedance; the intensity of the clinical pain was evaluated using the visual analog scale (VAS), and the symptoms of anxiety and depression, using the hospital's anxiety and depression scale (HAD).

Results The groups did not differ in terms of mean age, BMI, \%BF or regarding the available waist-to-hip ratio (WHR). The mean intensity of the clinical pain by the VAS was of $7.2 \pm 2.06$ in the group with CPP secondary to endometriosis, and of $5.93 \pm 2.64$ in the group with CPP secondary to other causes $(p=0.03)$, revealing significant differences between the groups.

Conclusion We concluded that, despite the difference in the pain score assessed between the two groups, there was no difference regarding body composition and anthropometry.

Objetivo Determinar a composição corporal média (porcentagem de gordura corporal), os marcadores antropométricos, e a intensidade de dor clínica em mulheres com diagnóstico clínico de dor pélvica crônica (DPC) secundária a endometriose.

Métodos Um estudo de caso-controle realizado com 91 mulheres, 46 das quais com DPC secundária a endometriose, e 45 das quais com DPC secundária a outras causas. As received January 23, 2020 accepted May 21, 2020
DOI https://doi.org/ 10.1055/s-0040-1713912. ISSN $0100-7203$.
Copyright $\odot 2020$ by Thieme Revinter

Publicações Ltda, Rio de Janeiro, Brazil
License terms

(c) $($ i 

Palavras-chave
- dor pélvica crônica
- percentual de gordura
- intensidade da dor
- ansiedade
- depressão

pacientes foram submetidas à avaliação dos parâmetros antropométricos por meio do índice de massa corporal (IMC), dos perímetros (cintura, abdômen, quadril), e do percentual de gordura corporal (\%GC), que foram avaliados em monitor de composição corporal por bioimpedância; a intensidade clínica da dor foi avaliada usando-se a escala visual analógica (EVA), e os sintomas de ansiedade e depressão, usando a escala de ansiedade e depressão do hospital (EADH).

Resultados Os grupos não diferiram quanto à idade média, ao IMC, ao \%GC, nem quanto à relação da cintura-quadril (RCQ) disponível. A média da intensidade clínica da dor pela EVA foi de 7,2 $\pm 2,06$ no grupo com DPC secundária a endometriose, e de $5,93 \pm 2,64$ no grupo com DPC secundária a outras causas $(p=0,03)$, revelando diferenças significativas entre os grupos. Em relação à EADH, ambos os grupos estavam acima da média de corte.

Conclusão Concluímos que, apesar da diferença no escore de dor avaliado entre os dois grupos, não houve diferença com relação à composição corporal e à antropometria.

\section{Introduction}

Chronic pelvic pain (CPP) is a frequent complaint in the gynecological practice, and it causes suffering, compromises the quality of life of the woman, and results in high costs to health systems. ${ }^{1}$ The prevalence of CPP is not well established, and it may vary from one country to another. However, it is estimated that $3.8 \%$ of women aged between 15 and 73 years, and between $14 \%$ to $24 \%$ of women of reproductive age present CPP. ${ }^{2}$ In Brazil, the prevalence is not well known; international studies have demonstrated a high prevalence of persistent pain in Brazilian women, 36\% in Rio de Janeiro, and $13 \%$ of women working in São Paulo. ${ }^{3}$ In the city of Ribeirão Preto, the detected prevalence was of $11.5 \%$, and $15.1 \%$ of these women are of reproductive age. ${ }^{4}$

Endometriosis is among the gynecological causes related to CPP, and its main clinical problem is painful syndrome, manifesting as dysmenorrhea, pelvic pain, abdominal pain, dyspareunia, and painful defecation. ${ }^{5}$ In women with CPP subjected to laparoscopy, the presence of endometriosis is higher than $30 \%{ }^{2}$ The mechanisms involved are not clear yet, and the nature of the pain associated with endometriosis has been poorly characterized. Evidence suggests that the pain may be caused by peritoneal inflammation, formation of adherences, and significant nervous injury, specific to endometriosis injuries, which are possibly correlated with a deep infiltration of the endometrial tissue. ${ }^{6}$

The scientific evidence of the relationship of overweight and obesity in women with CPP has not yet been clarified. The association between BMI and endometriosis has been studied; Viganò et al $^{7}$ concluded that women with endometriosis tend to be thinner than women without the disease, and the severity of the disease seems to be associated with the BMI. Yi et $\mathrm{al}^{8}$ showed that women with advanced diseases had lower BMIs than those with minimal or mild diseases.

Endometriosis is closely associated with alterations of the immune and endocrine systems, ${ }^{9}$ which are systems that are also associated with the control of obesity. To identify the etiological or mediating pathways associated with adiposity and endometriosis, one study ${ }^{10}$ has suggested that the adipose tissue has immune properties. It is possible that these immune properties of the adipose tissue are involved or affected by the development of endometriosis, which can arise from an alteration in immune functioning. ${ }^{9}$ The inhibition or promotion of immune cells may be linked to inflammation and to stimulation of angiogenesis. ${ }^{12}$

Overweight has a high prevalence among females, and it is even higher during perimenopause: it may affect $60 \%$ of the women in this stage of life, probably due to metabolic alterations inherent to this period. It is also associated with bad eating habits and genetic predisposition. ${ }^{13}$ The BMI and the percentage of body fat (\%BF) may be involved in the relationship between overweight and obesity, which can influence the report of painful perception in women with CPP. Han et $\mathrm{al}^{14}$ reported that an elevated waist-to-hip ratio (WHR) ${ }^{15}$ indicates a pattern of central obesity, and it was significantly associated with chronic low-back pain in women, but not in men. Planning an effective treatment might help in the early identification of problems related to CPP secondary to endometriosis, and reducing and relieving the distress suffered by these women is of great importance. Therefore, the present study aimed to evaluate whether there is a difference in average body composition (\%BF) through an evalution of the anthropometric markers of women diagnosed with CPP secondary to endometriosis and those diagnosed with CPP secondary to other causes. Moreover, we aimed to correlate the average body composition (\%BF) with the intensity of the clinical pain in these women.

\section{Methods}

The description of the present study was developed according to the Strengthening the Reporting of Observational 
Studies in Epidemiology (STROBE) ${ }^{16}$ guidelines (http://www. strobe-statement.org).

The present observational case-control study was approved by the Ethics Committee of the teaching hospital at Faculdade de Medicina de Ribeirão Preto, Universidade de São Paulo (HCFMRP-USP), as well as its informed consent form (ICF). Women diagnosed with CPP at the outpatient clinic of pelvic pain were invited to participate in the study before starting any treatment.

The adopted inclusion criteria were women aged between 18 and 49 years, with CPP secondary to endometriosis or to other possible causes for at least 6 months, intense enough to interfere in routine activities, and demanding clinical or surgical treatment. All patients were submitted to laparoscopy and histology for the diagnosis of endometriosis. Women at menopause, those who were smokers, pregnant, and breastfeeding for the previous six months were excluded from the study, as well as those who refused to participate. Informed consent was obtained before the intervention and after the patients received explanations.

The patients who agreed to participate in the study were scheduled for an evaluation and advised to fast for 12 hours and to not change their eating behavior, ${ }^{17}$ to not have products with caffeine: coffee, tea, and chocolate, ${ }^{18}$ alcohol, ${ }^{19}$ or medication ${ }^{20}$ in the 24 hours preceding the interview, in which questionnaires were filled out and data were collected. Age, anthropometric data, (body mass, height), the perimeters of the arm, waist, abdomen, and hip, as well as the \% $\mathrm{BF}$ were recorded.

To measure body mass and height, the women had to be barefoot, with no excess of clothes or accessories, with an erect body, the feet together, and the arms extended along the body, looking at a fixed point in the horizon. ${ }^{21}$ Measurements were made using a Filizola (São Paulo, SP, Brazil) digital scale (0.1-kg scale), with a capacity for $150 \mathrm{~kg}$ with a coupled stadiometer. With the combination of body mass and height, we calculared the BMI (BMI = body mass $/$ height $\left.^{2}\right){ }^{22}$

To verify the perimeters of the arm, waist, abdomen, and hip, a Sanny (São Bernardo do Campo, SP, Brazil) non-elastic tape with $1 \mathrm{~mm}$ of precision was used. According to ${ }^{23}$ the perimeter measurements, mainly the waist and hip perimeters are widely used, since they are fundamental to body composition.

The regional distribution of the \% $\mathrm{BF}$ arouses concern by virtue of the association among health complications resulting from metabolic and cardiovascular dysfunctions and a larger accumulation of fat in the central region of the body.

The \%BF was evaluated using the Model 310e. Bioimpedance Body Composition Monitor (Biodynamics Corporation, Shorelaine, WA, US). It sends a subthreshold electric current $(800 \mu \mathrm{A}, 50 \mathrm{kHz}$ - single frequency), with gel electrodes (Hearbeat, Conmed corp., NY, USA) for bioimpedance. ${ }^{24}$ It is a monitor that dysplays in a fast and precise way the amount of fat mass, lean mass, total body water, basal energy metabolism, and ideal weight. Its principle is based on electrical bioimpedamce, showing correlation levels, comparing to more accurate methods existing today. ${ }^{25}$ To compare the $\% \mathrm{BF}$, we used values of ideal $\% \mathrm{BF}$ according to
Lohman, ${ }^{26}$ classifying percentage from low (10\% to $15 \%$ ) to very high $(>30 \%)$.

To evaluate the intensity of the clinical pain, the visual analog scale (VAS) was used. ${ }^{27}$ It consists of a 10 -cm uninterrupted line in which the patient is instructed to check the score corresponding to the referred pain, keeping in mind that the beginning of the scale ( 0 ) corresponds to (no pain), and the end of the scale (10) corresponds to the "worst pain ever experienced or imagined." For the classification of the pain, we considered mild pain: $5 \mathrm{~mm}$ to $44 \mathrm{~mm}$; moderate pain: $45 \mathrm{~mm}$ to $74 \mathrm{~mm}$; and severe pain: $75 \mathrm{~mm}$ to $100 \mathrm{~mm}^{28}$

The statistical analysis was performed using the 2016 version of the SAS University (SAS Institute, Inc., , Cary, NC, US) software, ${ }^{29}$ and the results were shown as mean \pm standard deviation or median and variation according to the distribution. At first, an exploratory data analysis was performed using the measurements of central position of dispersion and normality graphs. Given the asymmetry of the distribution of some variables, the non-parametric Mann Whitney test was used to compare the distribution of the quantitative variables in relation to the study groups.

\section{Results}

In total, 122 women clinically diagnosed with CPP were invited to participate in the study. Of them, 96 took part in the evaluation, 5 of them were excluded because they were at menopause, a period that interferes in the \%BF, and 91 women remained: 45 were diagnosed with CPP secondary to other causes (the group was named CPP no endometriosis), and 46 women were diagnosed with CPP secondary to endometriosis (the group was named CPP endometriosis). The recruitment and evaluation took place from April 2014 to October 2015 (- Fig. 1).

- Table 1 shows the description and comparison between both groups in relation to the demographic variables.

The comparison of the demographic variables (age, marital status, schooling, profession) between the two groups did not reveal a significant difference. It is important to notice that in both groups there is a high prevalence of overweight women or women with with grade-I obesity, whereas only

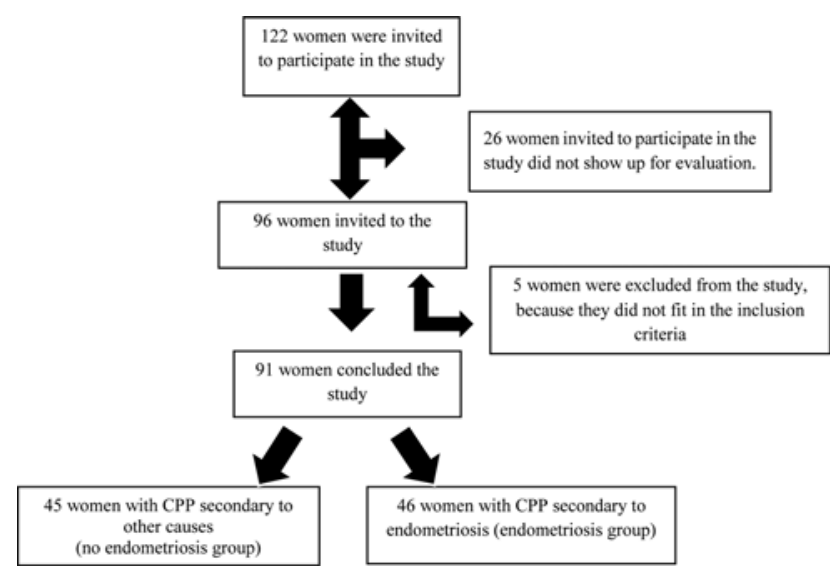

Fig. 1 Recruitment of the evaluated women with and without endometriosis. 
Table 1 Demographic characteristics of the women with CPP secondary to endometriosis and CPP secondary to other causes

\begin{tabular}{|c|c|c|c|c|c|}
\hline \multirow[t]{2}{*}{ Variables } & \multicolumn{2}{|c|}{ Endometriosis $(n=46)$} & \multicolumn{3}{|c|}{ No endometriosis $(n=45)$} \\
\hline & Mean & SD & Mean & SD & $p$-value \\
\hline \multirow[t]{2}{*}{ Age (years) } & 36.78 & \pm 7.58 & 38.33 & \pm 7.42 & 0.32 \\
\hline & Mean & SD & Mean & SD & $p$-value \\
\hline Parity & 1.42 & \pm 1.25 & 2.09 & \pm 1.24 & 0.17 \\
\hline Marital status & $\mathrm{n}$ & $\%$ & $\mathrm{n}$ & $\%$ & $p$-value \\
\hline Married & 31 & 68.9 & 34 & 73.91 & 0.59 \\
\hline Not married & 14 & 31.11 & 12 & 26.09 & \\
\hline Education & $\mathrm{n}$ & $\%$ & $\mathrm{n}$ & $\%$ & $p$-value \\
\hline Primary & 1 & 2.22 & 2 & 4.35 & 0.84 \\
\hline Elementary & 16 & 35.56 & 15 & 32.6 & \\
\hline High School & 19 & 42.22 & 22 & 47.83 & \\
\hline University & 9 & 20 & 7 & 15.22 & \\
\hline Profession & $\mathrm{n}$ & $\%$ & $\mathrm{n}$ & $\%$ & $p$-value \\
\hline Working & 30 & 65.91 & 31 & 68.89 & 0.76 \\
\hline Staying- at-home & 15 & 34.09 & 15 & 31.11 & \\
\hline
\end{tabular}

Abbreviations: CPP, chronic pelvic pain; SD, standard deviation.

Note: *p-values: non-parametric Mann Whitney test.

$20 \%$ of both groups present a nutritional-status classification as eutrophic, in other words, appropriate according to the BMI. To classify the nutritional status of the women in both groups, the BMI and the \%BF assessed by the electrical bioimpedance test were measured.

We observed that both groups had similar results regarding these variables, with no significant difference between them (-Table 2).
Regarding the anthropometric variables presented in -Table 3 (BMI, arm circumference, waist circumference, abdominal circumference, hip circumference, WHR and \%BF), no difference among the women with CPP secondary to endometriosis was found.

In relation to the pain in the VAS, which was evaluated in both groups, there was a significant difference $(p<0.05)$ between them (-Table 4).

Table 2 Description of the nutritional status according to body mass index (BMI) and percentage of body fat of women with CPP secondary to endometriosis and CPP secondary to other causes evaluated through an electrical bioimpedance exam

\begin{tabular}{|c|c|c|c|c|c|c|}
\hline \multirow[b]{2}{*}{ Classification } & \multirow[b]{2}{*}{ BMI $\left(\mathrm{kg} / \mathrm{m}^{2}\right)$} & \multicolumn{2}{|c|}{ Endometriosis } & \multicolumn{2}{|c|}{ No endometriosis } & \multirow[b]{2}{*}{$p$-value } \\
\hline & & $(n=45)$ & $\%$ & $(n=46)$ & $\%$ & \\
\hline Eutrophic & $18.5-24.9$ & 9 & $20 \%$ & 9 & $20 \%$ & 0.9519 \\
\hline Overweight & $25-29.9$ & 18 & $40 \%$ & 14 & $30 \%$ & \\
\hline Obesity (grade I) & $30-34.9$ & 12 & $27 \%$ & 10 & $22 \%$ & \\
\hline Obesity (grade II) & $35-39.9$ & 2 & $4 \%$ & 8 & $17 \%$ & \\
\hline Obesity (grade III) & $>40$ & 4 & $9 \%$ & 5 & $11 \%$ & \\
\hline Classification & $\begin{array}{l}\text { Percentage } \\
\text { of body fat }\end{array}$ & $(n=45)$ & $\%$ & $(n=46)$ & $\%$ & $p$-value \\
\hline Low & $10-15 \%$ & 0 & 0 & 0 & 0 & 0.0862 \\
\hline Great & $12-25 \%$ & 3 & $7 \%$ & 2 & $4 \%$ & \\
\hline Moderately high & $25-30 \%$ & 6 & $13 \%$ & 6 & $13 \%$ & \\
\hline High & $30-35 \%$ & 13 & $29 \%$ & 11 & $24 \%$ & \\
\hline Very high & $>30 \%$ & 23 & $51 \%$ & 27 & $59 \%$ & \\
\hline
\end{tabular}

Abbreviation: CPP, chronic pelvic pain. 
Table 3 Description of anthropometric variables (BMI, arm perimeter, waist perimeter, abdominal perimeter, hip perimeter, waistto-hip ratio and percentage of body fat) in women with CPP with endometriosis $(n=45)$ and CPP with no endometriosis ( $n=46)$

\begin{tabular}{|c|c|c|c|c|c|}
\hline \multirow[t]{2}{*}{ Anthropometric variables } & \multicolumn{2}{|c|}{ Endometriosis $(n=45)$} & \multicolumn{2}{|c|}{$\begin{array}{l}\text { No endometriosis } \\
(n=46)\end{array}$} & \multirow[t]{2}{*}{$p$-value } \\
\hline & Mean & SD & Mean & SD & \\
\hline BMI $(\mathrm{Kg} / \mathrm{m} 2)^{*}$ & 29.26 & \pm 6.23 & 30.84 & \pm 6.22 & 0.26 \\
\hline $\mathrm{AbP}(\mathrm{cm})$ & 30.63 & \pm 4.37 & 31.06 & \pm 4.94 & 0.83 \\
\hline WP $(\mathrm{cm})$ & 88.04 & \pm 13.47 & 90.98 & \pm 14.36 & 0.24 \\
\hline $\mathrm{AP}(\mathrm{cm})$ & 95.13 & \pm 13.67 & 98.39 & \pm 14.33 & 0.11 \\
\hline $\mathrm{HP}(\mathrm{cm})$ & 106.4 & \pm 12.97 & 107.2 & \pm 12.71 & 0.45 \\
\hline WHR & 0.83 & \pm 0.09 & 0.84 & \pm 0.76 & 0.19 \\
\hline Percentage of body fat & 34.92 & \pm 6.1 & 36.01 & \pm 6.22 & 0.27 \\
\hline
\end{tabular}

Abbreviations: AbP, abdominal perimeter; AP, arm perimeter; BMI, body mass index; HP, hip perimeter; WHR, waist-to-hip ratio; WP, waist perimeter. Note: $p$-values: non-parametric Mann Whitney test.

Table 4 Description of the mean scores on the unidimensional scales for pain intensity - Visual Analog Scale (VAS) of women with or without endometriosis

\begin{tabular}{llllll}
\hline Variables & Endometriosis & & \multicolumn{2}{l}{ No endometriosis } & \\
\hline Visual Analog Scale & $(n=45)$ & Standard deviation & $(n=46)$ & Standard deviation & $p$-value \\
& 7.2 & \pm 2.05 & 5.9 & \pm 2.62 & 0.03 \\
\hline
\end{tabular}

Note: $p$-values: non-parametric Mann Whitney test.

\section{Discussion}

In the present study, we performed an analysis of body composition using anthropometric markers, evaluating the \%BF compared with the intensity of clinical pain in women with a clinical diagnosis of CPP secondary to endometriosis and secondary to other causes. The groups were homogeneous in relation to the number of women evaluated and showed no difference in relation to the analyzed parameters and body composition.

A study ${ }^{7}$ demonstrated that women with endometriosis have physical characteristics of BMI below the classification that is considered for the healthy population: they are often thin, and do not present obesity in relation to the control subjects. Nevertheless, we observed in the present study that both groups showed a percentage of women with BMI above what is considered appropriate. However, the BMI does not necessarily represent an increase in adiposity, since it represents the total body mass, and not only adipose tissue mass, not reflecting the distribution of the \% $\mathrm{BF}^{30}$

Gurian et al, ${ }^{31}$ in their study, aimed to analyze anthropometric parameters (BMI and \%BF), and the clinical and experimental pain in women with CPP; the study revealed that a large part of the evaluated women presented a very high \%BF, in other words, risk of disease associated with obesity, ${ }^{32}$ as shown in the present study.

According to and Ley et $\mathrm{al}^{33}{ }^{33}$ the mean gain in body weight at perimenopause is estimated between $2 \mathrm{~kg}$ to $4 \mathrm{~kg}$ in 3 years, with an increase of $20 \%$ in total body fat. Therefore, as in the present study, the mean age of the women evaluated corresponds to the perimenopause phase, which can at least partly explain our results.
The \%BF in women with CPP shown in the present study was above the health levels recommended by the World Health Organization (WHO). ${ }^{23}$ Although there are few studies on body composition related to women with CPP and their secondary causes, ${ }^{31}$ such as endometriosis, we can understand that this increased percentage is probably due to certain factors, such as sedentary lifestyle, eating habits, metabolic alterations, and genetic predisposition. ${ }^{13}$

Several studies suggest that the adipose tissue has immune properties ${ }^{10}$ and differs depending on the type and location of the tissue, ${ }^{34}$ and that these properties may be involved or affected by the development of endometriosis. ${ }^{9}$ Women with endometriosis particularly present small amounts of adipose tissue (body fat) and adipose tissue below the waist (WHR). In the study by Shah et al, ${ }^{35}$ the waist circumference values showed a low relationship with endometriosis, and there was still no association between WHR and endometriosis. However, they suggest that a WHR below the recommended value may be related to up to a three-time higher chance of receiving the diagnosis of endometriosis. According to the present study, the WHR values between the groups did not show any difference, and this was the only ratio evaluated in the study.

Nevertheless, being thin is associated with the predominance of macrophages $\mathrm{M} 2$, whereas being overweight or obese is associated with the predominance of macrophages M1 (which promote inflammation and inhibit angiogenesis and tissue remodeling). ${ }^{36}$ We observed in the present study that, despite the fact that both groups had CPP, the endometriosis group showed a high \%BF, which was a finding that differed from those in the literature, and they also presented values higher than what is indicated for the region below the waist. Obesity is associated with significant increases in morbidity 
and mortality; obese patients are more prone to develop diseases, such as hypertension, dyslipidemia, type-II diabetes mellitus, coronary heart disease, cerebral vascular accident, pulmonary dysfunction, among other chronic diseases, as well aggaravation of the endometriosis. An in-depth investigation of the aspects of adiposity with endometriosis is necessary to identify etiological or mediating pathways between them. ${ }^{7}$

Visscher et $\mathrm{al}^{37}$ reported that the intensity of the pain has a great importance in the clinical practice, and it is recognized as one of the most relevant subjective pain experiences. The VAS is among the most widely used pain scales that aims to check the efficacy of the therapeutics and to compare the efficacy of different active treatments. It showed to be effective in the evaluation of the result of the treatments proposed in some randomized controlled trials applied to women with CPP of diverse causes; in them, the VAS was used as the primary outcome, as in the present study. ${ }^{38}$

The main limitation of the present study is the women evaluated in the group without endometriosis who had different etiologies and comorbidities, which were not considered separately, but we do not believe that this compromised the results.

\section{Conclusion}

We conclude that there was no difference in relation to body composition and the anthropometric parameters evaluated in both groups of patients with CPP (with or without endometriosis); however, the group of patients with endometriosis showed higher pain scores than the patients without endometriosis.

\section{Contributors}

All of the authors contributed with the project and the interpretation of the data, with the writing of the article, the critical review of the intellectual content, and with the final approval of the version to be published.

\section{Conflict to Interests}

The authors have no conflict of interests to declare.

\section{Acknowledgments}

We would like to thank Conselho Nacional de Desenvolvimento Científico e Tecnológico (Process:167553/2014-3).

\section{References}

1 Mathias SD, Kuppermann M, Liberman RF, Lipschutz RC, Steege JF. Chronic pelvic pain: prevalence, health-related quality of life, and economic correlates. Obstet Gynecol. 1996;87(03):321-327. Doi: 10.1016/0029-7844(95)00458-0

2 Gambone JC, Mittman BS, Munro MG, Scialli AR, Winkel CA; Chronic Pelvic Pain/Endometriosis Working Group. Consensus statement for the management of chronic pelvic pain and endometriosis: proceedings of an expert-panel consensus process. Fertil Steril. 2002;78(05):961-972. Doi: 10.1016/s0015-0282(02)04216-4

3 Gomes KRO, Tanaka ACA. [Reported morbidity and use of health services by working women, Brazil]. Rev Saude Publica. 2003;37 (01):75-82
4 Silva GPOG, Nascimento AL, Michelazzo D, Alves Junior FF, Rocha MG, Rosa e Silva JC, et al. High prevalence of chronic pelvic pain in women in Ribeirão Preto, Brazil and direct association with abdominal surgery. Clinics (São Paulo). 2011;66(08):1307-1312. Doi: 10.1590/S1807-59322011000800001

5 Farquhar C. Endometriosis. BMJ. 2007;334(7587):249-253

6 Vercellini P. Endometriosis: what a pain it is. Semin Reprod Endocrinol. 1997;15(03):251-261

7 Viganò P, Somigliana E, Panina P, Rabellotti E, Vercellini P, Candiani M. Principles of phenomics in endometriosis. Hum Reprod Update. 2012;18(03):248-259. Doi: 10.1093/humupd/dms001

8 Yi KW, Shin JH, Park MS, Kim T, Kim SH, Hur JY. Association of body mass index with severity of endometriosis in Korean women. Int J Gynaecol Obstet. 2009;105(01):39-42. Doi: 10.1016/j.ijgo.2008.11.001

9 Practice Committee of the American Society for Reproductive Medicine. Endometriosis and infertility: a committee opinion. Fertil Steril. 2012;98(03):591-598

10 Rasouli N, Kern PA. Adipocytokines and the metabolic complications of obesity. J Clin Endocrinol Metab. 2008;93(11, Suppl 1): S64-S73. Doi: 10.1210/jc.2008-1613

11 Mandal P, Pratt BT, Barnes M, McMullen MR, Nagy LE. Molecular mechanism for adiponectin-dependent M2 macrophage polarization: link between the metabolic and innate immune activity of full-length adiponectin. J Biol Chem. 2011;286(15):13460-13469. Doi: 10.1074/jbc.M110.204644

12 Adya R, Tan BK, Chen J, Randeva HS. Protective actions of globular and full-length adiponectin on human endothelial cells: novel insights into adiponectin-induced angiogenesis. J Vasc Res. 2012; 49(06):534-543. Doi: 10.1159/000338279

13 Lins APM, Sichieri R. Influência da menopausa no índice de massa corporal. Arq Bras Endocrinol Metabol. 2001;45(03):265-270. Doi: 10.1590/S0004-27302001000300009

14 Han TS, Schouten JS, Lean ME, Seidell JC. The prevalence of low back pain and associations with body fatness, fat distribution and height. Int J Obes Relat Metab Disord. 1997;21(07):600-607. Doi: 10.1038/sj.ijo.0800448

15 González-Ramos R, Donnez J, Defrère S, Leclercq I, Squifflet J, Lousse JC, et al. Nuclear factor-kappa B is constitutively activated in peritoneal endometriosis. Mol Hum Reprod. 2007;13(07): 503-509. Doi: 10.1093/molehr/gam033

16 Probing STROBE. Epidemiology. 2007;18(06):789-790. Doi: 10.1097/EDE.0b013e318157752d

17 Machado RB, Tachotti F, Cavenague G, Maia E. Effects of two different oral contraceptives on total body water: a randomized study. Contraception. 2006;73(04):344-347. Doi: 10.1016/j. contraception.2005.09.014

18 Straneva PA, Maixner W, Light KC, Pedersen CA, Costello NL, Girdler SS. Menstrual cycle, beta-endorphins, and pain sensitivity in premenstrual dysphoric disorder. Health Psychol. 2002;21(04): 358-367. Doi: 10.1037/0278-6133.21.4.358

19 Fernández G, Weis S, Stoffel-Wagner B, Tendolkar I, Reuber M, Beyenburg S, et al. Menstrual cycle-dependent neural plasticity in the adult human brain is hormone, task, and region specific. J Neurosci. 2003;23(09):3790-3795. Doi: 10.1523/JNEUROSCI.2309-03790.2003

20 Bajaj P, Arendt-Nielsen L, Bajaj P, Madsen H. Sensory changes during the ovulatory phase of the menstrual cycle in healthy women. Eur J Pain. 2001;5(02):135-144. Doi: 10.1053/eujp.2001.0236

21 Petroski EL. Antropometria: técnicas e padronizações. Porto Alegre: Pallotti; 1999

22 Queiroga MR, Ferreira SA, Romanzini M. Perfil antropométrico de atletas de elite do futsal feminino conforme a função tática do jogo. Rev Bras Cineantropom Desempenho Hum. 2005;7(01):30-34

23 Word Heath Organization. Obesity: preventing and managing the global epidemic. Report of a WHO consultation on obesity. Geneva: WHO; 1998 
24 Eickemberg M, Oliveira CC, Roriz AKC, Sampaio LR. Bioimpedância elétrica e sua aplicação em avaliação nutricional. Rev Nutr. 2011; 24(06):873-882. Doi: 10.1590/S1415-52732011000600009

25 Ellis KJ. Human body composition: in vivo methods. Physiol Rev. 2000;80(02):649-680. Doi: 10.1152/physrev.2000.80.2.649

26 Lohman TG. Advances in body composition assessment. Champaign: Human Kinetics; 1991

27 Kane RL, Bershadsky B, Rockwood T, Saleh K, Islam NC. Visual Analog Scale pain reporting was standardized. J Clin Epidemiol. 2005;58(06):618-623. Doi: 10.1016/j.jclinepi.2004. 11.017

28 Jensen MP, Chen C, Brugger AM. Interpretation of visual analog scale ratings and change scores: a reanalysis of two clinical trials of postoperative pain. J Pain. 2003;4(07):407-414. Doi: 10.1016/s15265900(03)00716-8

29 Statistical Analysis System Institute. Statistical Analysis System user's guide. Version 9.1. Cary: SAS Institute; 2016

30 Holdsworth-Carson SJ, Dior UP, Colgrave EM, Healey M, Montgomery GW, Rogers PA, et al. The association of body mass index with endometriosis and disease severity in women with pain.J Endometr Pelvic Pain Disord. 2018;10(02):79-87. Doi: 10.1177/22840265 18773939

31 Gurian MB, Mitidieri AM, da Silva JB, da Silva AP, Pazin C, Poli-Neto $\mathrm{OB}$, et al. Measurement of pain and anthropometric parameters in women with chronic pelvic pain. J Eval Clin Pract. 2015;21(01): 21-27. Doi: 10.1111/jep.12221
32 Heyward VH, Stolarczyk LM. Applied body composition assessment. Champaign: Human Kinetics; 1996

33 Ley CJ, Lees B, Stevenson JC. Sex- and menopause-associated changes in body-fat distribution. Am J Clin Nutr. 1992;55(05): 950-954. Doi: 10.1093/ajen/55.5.950

34 Vatier C, Kadiri S, Muscat A, Chapron C, Capeau J, Antoine B. Visceral and subcutaneous adipose tissue from lean women respond differently to lipopolysaccharide-induced alteration of inflammation and glyceroneogenesis. Nutr Diabetes. 2012;2:e51. Doi: 10.1038/nutd.2012.29

35 Shah DK, Correia KF, Vitonis AF, Missmer SA. Body size and endometriosis: results from 20 years of follow-up within the Nurses' Health Study II prospective cohort. Hum Reprod. 2013;28 (07):1783-1792. Doi: 10.1093/humrep/det120

36 Lumeng CN, Bodzin JL, Saltiel AR. Obesity induces a phenotypic switch in adipose tissue macrophage polarization. J Clin Invest. 2007;117(01):175-184. Doi: 10.1172/JCL29881

37 Visscher CM, Lobbezoo F, Naeije M. Comparison of algometry and palpation in the recognition of temporomandibular disorder pain complaints. J Orofac Pain. 2004;18(03):214-219

38 Zullo F, Palomba S, Zupi E, Russo T, Morelli M, Cappiello F, et al. Effectiveness of presacral neurectomy in women with severe dysmenorrhea caused by endometriosis who were treated with laparoscopic conservative surgery: a 1-year prospective randomized double-blind controlled trial. Am J Obstet Gynecol. 2003;189 (01):5-10. Doi: 10.1067/mob.2003.358 